ISSN 1119-7455

\title{
PRODUCTION AND QUALITY ASSESSMENT OF MAYONNAISE FROM BLENDS OF SOYBEAN OIL AND AFRICAN PEAR (Dacryodes edulis) PULP OIL
}

\author{
*Onwuzuruike U.A., Okakpu C.J., Ndife J. and Eke C.I. \\ Department of Food Science \& Technology, \\ Michael Okpara University of Agriculture, Umudike, Nigeria \\ *Corresponding author's email: onwuzuruike.uzochukwu@mouau.edu.ng
}

\begin{abstract}
Mayonnaise is an oil-in-water emulsion rich in calorie, micronutrients and fat-soluble vitamins which is produced from dominantly vegetable oil. African pear oil is a highly unsaturated oil, domestically and commercially underutilize with tonnage of postharvest losses. It presently, has little or no industrial attraction for use as commercial ingredient for food production and formulation. The aim therefore is to improve the commercial value of African pear pulp oil for use as a main ingredient in food applications, hence improving its utilization and reducing postharvest losses. Oil was extracted from African pear through Soxhlet extraction using n-hexane as the solvent and the extracted oil was blended with soybean oil in the following ratios: SO100:APOO (Control), SO0:APO100, SO85:APO15, SO75:APO25, SO65:APO35, and SO50:APO5O for the production of mayonnaise. Some physicochemical properties of the oil blends were evaluated while proximate and sensory properties were also evaluated in the produced mayonnaise. Blending increased the iodine, acid and free fatty acid values of the oil blends and decreased significantly $(p<0.05)$ the peroxide value. The values ranged from 30.65 to $124.00 \mathrm{~g}$ iodine $100 \mathrm{~g}^{-1}, 6.85$ to $2.57 \mathrm{mg} \mathrm{KOH} \mathrm{g}{ }^{-1}, 5.03$ to $1.91 \%$ and 2.62 to $3.50 \mathrm{meq} \mathrm{O}_{2} \mathrm{~kg}^{-1}$ for iodine, acid, free fatty acid and peroxide values, respectively. The proximate composition parameters of the mayonnaise samples increased significantly $(p<0.05)$ after blending. The values ranged from 32.65 to $35.04 \%$ for moisture, 1.12 to $1.44 \%$ for ash, 30.15 to $37.15 \%$ for fat, 1.93 to $2.31 \%$ for protein and 25.87 to $34.15 \%$ for carbohydrate. Significant improvement was recorded in the values of vitamin $E$, iodine and viscosity values of the mayonnaise samples after blending compared to the control with values

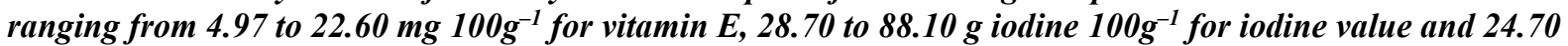
to 30.13 Pa.s for viscosity. Sensory evaluation showed that the mayonnaise samples were generally acceptable by the panelists. Conclusively, blending soybean oil with African pear oil up to 50:50 could be used in the production of acceptable mayonnaise with higher fat, protein, ash, vitamin E, iodine value and viscosity, thereby reducing its postharvest losses through improved utilization.
\end{abstract}

Key words: African pear oil, mayonnaise, soybean, quality, Dacryodes edulis

\section{INTRODUCTION}

Mayonnaise is a semisolid oil-in-water emulsion that is basically made by blending vegetable oil, vinegar, egg yolk (Mirzanajafi-Zanjani et al., 2019), emulsifier, flavouring agents like mustard, and so on (Yildirim et al., 2016). Mayonnaise is vital in the food system as it is used in the preparation of numerous dishes like salads and can be consumed by both children and adults (Aleksandrs et al., 2016). It is a good source of calories, micronutrients like calcium, magnesium, vitamins $\mathrm{A}$ and $\mathrm{E}$, as well as linoleic acid and alpha-linolenic acids which are highly unique and of health importance (Aswir et al., 2017). It is prepared using a wide array of edible oil which provides a base for the rest of the ingredients (Ghulam et al., 2013), provide energy, essential fatty acids and serve as a carrier of fat-soluble vitamins (Zahir et al., 2014; Ravisankar et al., 2015).
Kusuma (2015) reported that soybean is a rich source of isoflavones which has a wide array of health benefits like lowering of blood cholesterol level. Soybean oil comprises of 17.00 to $19.00 \%$ of soybean dry weight, of which most is polyunsaturated fatty acids (Sharma et al., 2014). Kusuma (2015) stated that soybean oil contributes to $28.00 \%$ of the world's edible oil, and is second in the production of edible oils to palm oil (O'Keefe et al., 2015). Despite its high nutritional significance, soybean produces less oil yield and its more expensive compared to many local seed oils. Additionally, a few side effects of soybean oil include allergies in persons who are hypersensitive to soybean and other soy-products, for instance, problems like gynecomastia, changes in mood and obesity which is more pronounced in men due to increase in estrogen levels (Mateos-Asparicio et al., 2008).

Please cite as: Onwuzuruike U.A., Okakpu C.J., Ndife J. and Eke C.I. (2022). Production and quality assessment of mayonnaise from blends of soybean oil and African pear (Dacryodes edulis) pulp oil. Agro-Science, 21 (1), 88-97. DOI: https://dx.doi.org/10.4314/as.v21i1.14 
The African pear (Dacryodes edulis) is basically known as "bush butter" and "native pear" (Miguel $e t$ al., 2017) in Togo, Ghana and Cameroon, while among the Ibo-speaking people of southeastern Nigeria, it is known as "ube" (Omonhinmin, 2014). Its pulp has high oil yield (49.57 to $52.9 \%)$ (Enengedie et al., 2019) aside possessing saturated fatty acids $(45.53 \%)$, monounsaturated fatty acids $(30.81 \%)$ and polyunsaturated fatty acids $(23.59 \%)$ (Noumi et al., 2014). African pear pulp oil has a viscosity of 42.24 centistokes, density of $0.89 \mathrm{~g} \mathrm{~cm}^{-3}$, refractive index of 1.47 , smoke point of $190.39^{\circ} \mathrm{C}$ (Akusu and Wordu, 2019), acid value of 0.34-0.46 $\mathrm{mg} \mathrm{KOH} \mathrm{g}^{-1}$, saponification value of 180.89-189.77 $\mathrm{mg} \mathrm{KOH} \mathrm{g}{ }^{-1}$, peroxide value of $12.86-22.75 \mathrm{meq} \mathrm{O}_{2}$ $\mathrm{kg}^{-1}$ and iodine value of $32.47-37.11 \mathrm{~g}$ iodine $100 \mathrm{~g}^{-1}$ (Adedokun and Onuegbu, 2011). Like other vegetable oils, African pear pulp oil has the potential to be used in the processing of several food products like spreads and shortening (Akusu et al., 2019), thereby reducing postharvest losses.

Postharvest losses refer to losses that occur at harvest, storage, transportation, processing, marketing and preparation before consumption. It is prevalent in developing countries like Nigeria (Noumi et al., 2014). African pear fruits like other fruits are seasonal, being matured within the months of May and June (Ndah et al., 2013). During this period, its high respiratory rate, ethylene production, poor processing information and knowledge increases its postharvest losses thus, militating against food security in Nigeria (Isaac et al., 2014). Aside this, considerable research has been conducted to identify other plant-based substitutes to common oils such as soybean oil used in mayonnaise production, but there is a dearth of information on the application of African pear pulp oil in mayonnaise production.

There is need to reduce its postharvest losses by incorporating its oil in value added products like mayonnaise by blending with other edible oils. Blending of oils helps to obtain desirable characteristics of different oils in single oil and to formulate oil which has balanced fatty acid profile, high stability, rich in bioactive compounds, beneficial for human health with high functionality and industrial value. This study is therefore aimed at investigating the quality of mayonnaise produced from African pear pulp oil and soybean oil blends.

\section{MATERIALS AND METHODS \\ Source of Raw Materials}

African pear fruits (Figure 1) and ingredients for mayonnaise production were purchased at Ubani Main Market in Umuahia, Abia State, Nigeria. Soybean oil (control) was purchased from Shoprite Mall, Umuahia. All the reagents used for laboratory analysis were of analytical grade and were purchase from a certified reagent store at Aba, Abia State, Nigeria.

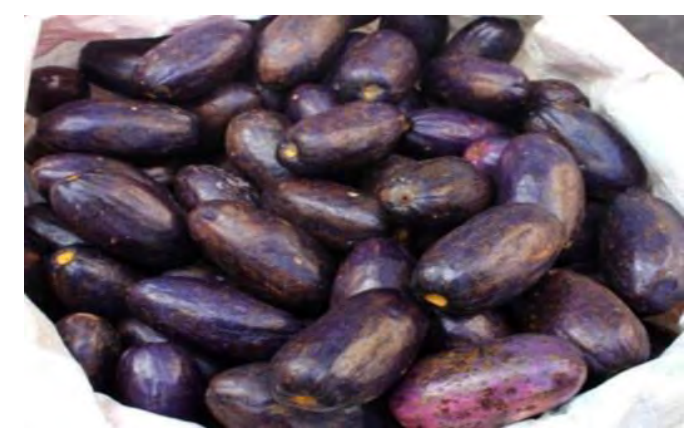

Figure 1: African pear (Dacryodes edulis) fruits

\section{Processing of African Pear Pulp into Powder}

The method described by Okolo et al. (2016) was used in processing African pear pulp into powder for Soxhlet extraction. Two kilogram of African pear fruit were sorted, washed with distilled water and deseeded with the aid of a sharp stainless-steel knife. The pulp was cut into small pieces $(1.5 \mathrm{~cm})$ before drying in an electronic oven (Gallenkemp, 300 Plus, England) at $45^{\circ} \mathrm{C}$ for $48 \mathrm{~h}$. Thereafter, the dried African pear pulp was pulverized with an electric blender (Osterizer, Model 120V, 50-60 Hz Frequency, 400 watts, Mexico) to obtain African pear pulp powder (Figure 2).

\section{Extraction of African Pear Pulp Oil}

The method of described by Musa et al. (2015) was adopted and used for extraction of African pear pulp oil using Soxhlet extraction method. Fifty milliliters $(50 \mathrm{ml}) \mathrm{n}$-hexane was first introduced into a $500 \mathrm{ml}$ round bottom flask. African pear pulp powder (10 g) was measured into a thimble and was inserted at the center of the Soxhlet extractor. The extractor was then heated to $65^{\circ} \mathrm{C}$ for $5 \mathrm{~h}$ and was held at that temperature during the extraction process. As the solvent began to boil, the vapour rose through the vertical tube of the extractor into the condenser at the top of extractor. The liquid condensate then dripped into the filter paper thimble in the centre which contained the solid sample from which oil is extracted. The extract seeped through the pores of the thimble and filled the siphon tube, where it flowed back down into the round bottom flask. The extract was then removed from the set-up, dried in the oven at $70^{\circ} \mathrm{C}$, cooled in desiccators and weighed again to determine the amount of oil extracted. The oil sample was packaged in an airtight bottle container (Figure 3) for further use. This process was repeated until the needed quantity of oil was extracted.

\section{Determination of Percentage Oil Yield}

The oil yield was calculated by taking into account the mass of the extracted African pear pulp oil and the mass of the African pear pulp used for oil extraction as described by Rebolleda et al. (2012):

$$
\text { Oil yield (\%) }=\frac{\text { Mass of extracted oil }}{\text { Mass of Dacryodes edulis pulp }} \times 100 \text {. }
$$




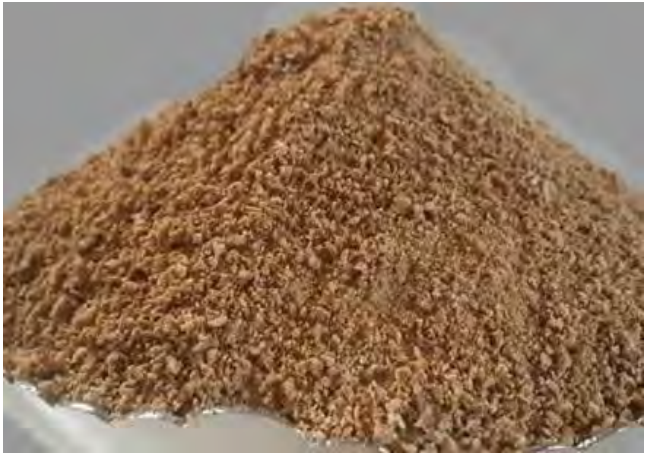

Figure 2: African pear pulp powder

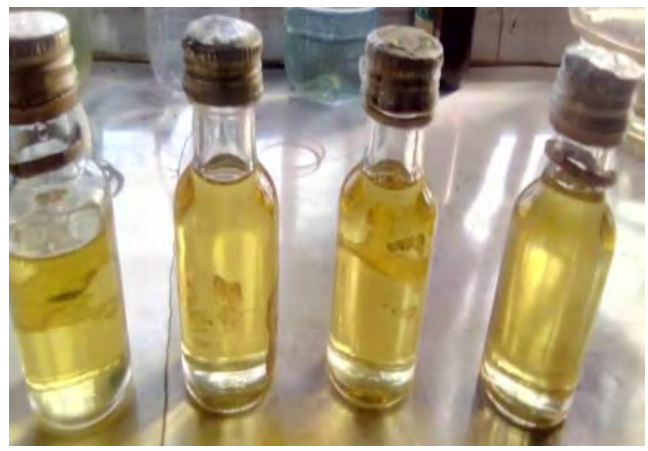

Figure 3: African pear pulp oil

\section{Oil Blend Formulation}

Soybean oil and African pear pulp oil samples were blended in varying proportions as shown in Table 1.

\section{Evaluation of Some Chemical Properties of the Oil Blends}

The method described by AOCS (1993) was used to determine peroxide value of the oil blends. The method of ASTM (2012) was used to determine the iodine value of the oil blends. Free fatty acid and acid values were determined using the method described by Ankapong (2010).

\section{Mayonnaise Production}

Mayonnaise was processed using the recipe in Table 2 and according to the method described by Ghulam et al. (2013). Mustard powder, sugar and salt were mixed together before addition of vinegar. Thereafter,

Table 1: Formulation of oil blend

\begin{tabular}{lcc}
\hline Sample codes (\%) & Soybean oil & African pear pulp oil \\
\hline Control & 100.00 & 0.00 \\
SO0:APO100 & 0.00 & 100.00 \\
SO85:APO15 & 85.00 & 15.00 \\
SO75:APO25 & 75.00 & 25.00 \\
SO65:APO35 & 65.00 & 35.00 \\
SO50:APO50 & 50.00 & 50.00 \\
\hline SO - soybean oil, APO - African pear oil; numerical values \\
\multicolumn{2}{l}{ standing for the percentages of each oil }
\end{tabular}

Table 2: Recipe for production of mayonnaise

\begin{tabular}{lc}
\hline Ingredients & Quantity $(\mathrm{g})$ \\
\hline Vegetable oil & 70.00 \\
Vinegar & 11.00 \\
Egg yolk & 10.50 \\
Distilled water & 3.50 \\
Salt & 2.00 \\
Sugar & 1.50 \\
Mustard powder & 1.50 \\
\hline Source: Belal et al. (2019) &
\end{tabular}

they were stirred together for $2 \mathrm{~min}$. before adding vegetable oil gently as stirring continued for additional $5 \mathrm{~min}$. to obtain mayonnaise. The mayonnaise samples were placed inside air-tight plastic containers and stored in a refrigerator $\left(4-8^{\circ} \mathrm{C}\right)$ before assessment.

Proximate Determination of Mayonnaise Samples The proximate composition of the mayonnaise samples, including the fat, moisture, crude protein (with nitrogen content converted to crude protein by a conversion factor of 6.25), ash, crude fibre of the mayonnaise samples according to the method of AOAC (2012). Fat was determined using a Soxhlet apparatus. Crude protein of the mayonnaise was determined using the Kjedahl method. Carbohydrate was estimated by difference, i.e., $100 \%-\%$ (moisture + crude protein + fat + crude fibre + ash).

Physicochemical Analysis of Mayonnaise Samples The $\mathrm{pH}$ and total solids of the mayonnaise was determined by the method described by Onwuka (2014). The method of ASTM (2012) was used in determining the vitamin $\mathrm{E}$ content and iodine value of the mayonnaise sample. The viscosity was measured according to the method of ASTM (2011).

\section{Sensory Evaluation}

A 20-member semi trained panel, aged 18 to 27 years old and composed of 14 females and 6 males, evaluated sensory properties of the mayonnaise samples. Panellists were trained according the method of Iwe (2014). Each sample were placed on 3-digit coded white saucer and presented to the panellists for analysis. Panellists were also presented with score sheets coded on a 9-point hedonic scale ranging from 1 for disliked extremely to 9 for liked extremely and sachets of water to rinse their mouth after tasting each sample to prevent carry over aftertaste. After sensory analysis, data were collated from score sheets for statistical analysis.

\section{Statistical Analysis}

One-way analysis of variance was carried out on the data generated in this study using the SPSS version 19.0 software. The analyzed data were expressed as means alongside their respective standard deviations. The Duncan multiple range test was used to compare the means of experimental data at $95 \%$ confidence interval when a difference has been reported to exist.

\section{RESULTS AND DISCUSSION \\ Oil Yield of Extracted African Pear Oil}

The percentage oil yield of extracted African pear pulp oil through the solvent extraction using nhexane as the solvent was $36.01 \%$. This value is close to the value (34.09\%) obtained by Onwuzuruike et al. (2020) for African pear pulp oil extracted by Soxhlet extraction method with n-hexane as the solvent but higher than the value $(18.28 \%)$ reported by Arrisson et al. (2019) for this same African pear pulp oil extracted by solvent extraction method with petroleum ether as the solvent. 
Previous studies by Ikya et al. (2013), Arrisson et al. (2019) and Onwuzuruike et al. (2020) suggested that Soxhlet extraction method might provide a better yield of vegetable oil than hot water (traditional) and screw press extraction methods so far investigated. This assertion was based on the fact that the milling process prior to extraction increased the surface area for solvent penetration to bring out the oil by leaching. Also, the high temperature and long-time associated with Soxhlet extraction could have played a major role in dissolving the fat globules and allowing an extended time for sufficient extraction, respectively.

\section{Quality Characteristics of Oil Blends}

The quality characteristics of oil blends as presented in Table 3 were affected significantly $(p<0.05)$ by blending ratio. The iodine value (IV) ranged from 30.65 to $124.15 \mathrm{~g}$ iodine $100 \mathrm{~g}^{-1}$. IV is the mass of iodine in grams that is consumed by $100 \mathrm{~g}$ of oil (Sadoudi and Ali-Ahmed, 2017). It indicates the degree of unsaturation in a vegetable oil (Asuquo et al., 2012), as well as its susceptibility to oxidation and rancidity (Agbaire, 2012). The oil blends had a higher iodine value (114.05-124.00 g iodine $100 \mathrm{~g}^{-1}$ ) than the control $\left(82.00 \mathrm{~g}\right.$ iodine $\left.100 \mathrm{~g}^{-1}\right)$ and SO0:APO100 (100\% African pear pulp oil) which suggested possible increase in the level of unsaturation after blending (Roiaini et al., 2015). Increase in unsaturated fatty acids in edible oils are good for human health as compared to saturated fatty acids, but they are highly unstable at high temperature and easily undergo oxidation. The iodine value of the oil blends was within the recommended limit for iodine (90-125 $\mathrm{g}$ iodine $100 \mathrm{~g}^{-1}$ ) as stipulated by FAO/WHO (2009). The IV obtained in this study was above $58.54 \mathrm{~g}$ iodine $100 \mathrm{~g}^{-1}$ reported for Citrullus vulgaris seed oil (Onoriode et al., 2015), whereas 89.04, $93.48,87.75$ and $83.26 \mathrm{~g}$ iodine $100 \mathrm{~g}^{-1}$ reported by Hasan et al. (2019) for unblended commercial black cumin oil, sesame oil, mustard oil, and olive oil respectively were within range of iodine obtained in this study. Also, the value obtained for SO0:APO100 was in agreement with the value reported by Onwuzuruike et al. (2020) for differently extracted African pear pulp oil (31.00-36.00 g iodine $100 \mathrm{~g}^{-1}$ ). The higher iodine value of the oil blends suggested that it may likely be healthier for consumption. This is because oils with high IV have been reported to reduce the level of low-density lipoproteins, reduce inflammation and build stronger cell membranes in the body (Sunmonu et al., 2016).
The peroxide value (PV) of the oil samples ranged from 2.62 in the control to 3.50 meq $\mathrm{O}_{2} \mathrm{~kg}^{-1}$ in SO50:APO50. The PV is a measure of oxidation during storage and the freshness of the lipid matrix (Atinafu and Bedemo, 2011). Yang et al. (2016) reported that PV aids to monitor the oxidative stability of vegetable oil. The lowest PV obtained in the control suggested lower concentration of hydrogen peroxides, a primary oxidation product. The values obtained in this study was lower than 1.85-5.24 meq $\mathrm{O}_{2} \mathrm{~kg}^{-1}$ reported for selected brands of vegetable oils sold in Umuahia metropolis, Abia State, Nigeria (Ukom et al., 2018) and 8.80 meq $\mathrm{O}_{2} \mathrm{~kg}^{-1}$ reported for sunflower oil (Mengistie et al., 2018). The value of SO0:APO100 (2.88 meq $\left.\mathrm{O}_{2} \mathrm{~kg}^{-1}\right)$ was close to the value reported by Onwuzuruike et al. (2020) (2.55 meq $\mathrm{O}_{2} \mathrm{~kg}^{-1}$ ) for African pear pulp oil extracted through Soxhlet extraction method using n-hexane as the solvent. A maximum limit of 10 meq $\mathrm{O}_{2} \mathrm{~kg}^{-1}$ has been set by Codex Alimentarius Commission for vegetable oils (CODEX, 1999). Blending increased the PV but did not adversely affect it since they were below the maximum limit, consequently, the oil samples could be considered fresh.

The free fatty acid (FFA) of the oil samples was reduced after blending, specifically from $5.03 \%$ in $100 \%$ African pear oil (SO0:APO100) to $1.91 \%$ in SO85:APO15. The FFA values showed significant $(p<0.05)$ differences among the oil samples except for SO75:APO25 and SO65:APO35. The FFA is a measure of the suitability of a vegetable oil for any direct consumption or industrial application (AlBachir, 2015). Higher value of FFA obtained in SO0:APO100 compared to the refined oil (control) could probably be due to refining process. The control has gone through the process of oil refining to remove FFAs through alkaline treatment. Notably, the blended oils have lower FFA compared to the control and SO0:APO100 which is very beneficial since low FFA results to lower cost and energy required for refining. The FFA value obtained for SO0:APO100 (5.03\%) agrees with the value reported by Onwuzuruike et al. (2020) (2.12-5.13\%) for African pear pulp oil extracted using different extractions methods. The FFA values obtained in this study exceeded that $(0.05-0.5 \%)$ recommended by the Codex Alimentarius Commission (CODEX, 1999) which suggested that the oil samples may exhibit a faster rate of hydrolytic rancidity and may be unsuitable for human consumption.

Table 3: Quality characteristics of oil blends

\begin{tabular}{lcccc}
\hline Samples & Iodine value $\left(\mathrm{g} 100 \mathrm{~g}^{-1}\right)$ & Peroxide value $\left(\mathrm{meq} \mathrm{O}_{2} \mathrm{~kg}^{-1}\right)$ & Free fatty acid (\%) & Acid value $\left(\mathrm{mg} \mathrm{KOH} \mathrm{g}^{-1}\right)$ \\
\hline Control & $82.00 \pm 0.57^{\mathrm{e}}$ & $2.62 \pm 0.06^{\mathrm{b}}$ & $2.81 \pm 0.01^{\mathrm{b}}$ & $2.57 \pm 0.04^{\mathrm{e}}$ \\
SO0:APO100 & $30.65 \pm 0.21^{\mathrm{f}}$ & $2.88 \pm 0.03^{\mathrm{ab}}$ & $5.03 \pm 0.07^{\mathrm{a}}$ & $6.85 \pm 0.04^{\mathrm{a}}$ \\
SO85:APO15 & $124.15 \pm 1.41^{\mathrm{a}}$ & $3.05 \pm 0.03^{\mathrm{ab}}$ & $1.91 \pm 0.02^{\mathrm{e}}$ & $3.47 \pm 0.02^{\mathrm{d}}$ \\
SO75:APO25 & $114.05 \pm 1.78^{\mathrm{d}}$ & $2.74 \pm 0.76^{\mathrm{ab}}$ & $1.95 \pm 0.01^{\mathrm{d}}$ & $3.91 \pm 0.01^{\mathrm{b}}$ \\
SO65:APO35 & $117.60 \pm 0.99^{\mathrm{c}}$ & $3.42 \pm 0.01^{\mathrm{ab}}$ & $1.97 \pm 0.03^{\mathrm{d}}$ & $3.96 \pm 0.01^{\mathrm{b}}$ \\
SO50:APO50 & $121.15 \pm 1.20^{\mathrm{b}}$ & $3.50 \pm 0.03^{\mathrm{a}}$ & $2.01 \pm 0.01^{\mathrm{c}}$ & $3.65 \pm 0.01^{\mathrm{c}}$ \\
SO - soybean oil, APO - African pear oil; numerical values standing for the percentages of each oil &
\end{tabular}

Values (means \pm std dev. of duplicate determination) in the same column with different superscript are significantly different $(p<0.05)$. 
The acid values (AV) of the oil samples were significantly $(p<0.05)$ different from each other. The values ranged from 2.57 to $6.85 \mathrm{mg} \mathrm{KOH} \mathrm{g}{ }^{-1}$. Blending improved the AV of the oil samples (3.47$3.96 \mathrm{mg} \mathrm{KOH} \mathrm{g}^{-1}$ ) compared to $100 \%$ African pear pulp oil (SO0:APO100) (6.85 $\mathrm{mg} \mathrm{KOH} \mathrm{g}^{-1}$ ). The control had the lowest $\mathrm{AV}$, possibly due to the process of refining the oil was subjected to and the presence of synthetic antioxidants used in oil refining in addition to any natural antioxidants. The $\mathrm{AV}$ is a measure of the free fatty acids in oil (Enengedie et al., 2019). It provides information on the extent of the decomposition of triglycerides in the oil by lipase action into free fatty acids (Ochigbo and Paiko, 2011). The higher AV recorded in SO0:APO100 suggested the presence of higher levels of free fatty acids (FFA) due to its crude form, which translates into decreased oil quality (Katkade et al., 2018). The values obtained in this study was in agreement with the value $\left(3.76 \mathrm{mg} \mathrm{KOH} 100 \mathrm{~g}^{-1}\right)$ reported by Okonkwo and Okafor (2016) for Gossypium hirsutum oil, lower than $19.21 \mathrm{mg} \mathrm{KOH}$ $100 \mathrm{~g}^{-1}$ reported for soybean oil but higher than the value (4.63 $\mathrm{mg} \mathrm{KOH} 100 \mathrm{~g}^{-1}$ ) reported for groundnut oil (Amos-Tautua and Onigbinde, 2013), except SO0:APO100 which had $6.85 \mathrm{mg} \mathrm{KOH} \mathrm{g}^{-1}$ as its AV. According to CODEX (1999), the AV of vegetable oil suitable for edible purposes should not exceed $4 \mathrm{mg} \mathrm{KOH} \mathrm{g} \mathrm{g}^{-1}$. Hence, the blended oil samples might be more suitable for edible purposes.

Proximate Composition of Mayonnaise Samples Table 4 shows that blending of soybean and African pear oil for mayonnaise production affected the proximate composition significantly $(p<0.05)$. The moisture content (MC) of the mayonnaise samples produced from oil blends were higher. The values ranged from 32.65 to $35.04 \%$. The value obtained in this study was lower than $48.80 \%$ reported for Heinz ${ }^{\circledR}$ mayonnaise (Babajide and Olatunde, 2010), 41.94 to $46.95 \%$ reported by Palma et al. (2004) for low fat mayonnaise samples but higher than 15.16 to $15.30 \%$ reported for mayonnaise processed with different proportions of corn oil (Muhammad et al., 2013). Food samples with low MC exhibit better shelf stability (Abitogun and Olasehinde, 2012; Nangbes et al., 2013). Some variations in moisture content in mayonnaise might be due to variation in the chemical composition of oils, blending time and slight variations in the amount of water added due to instrumental error (Prescott and Board, 1993).
The values for ash ranged from 1.12 to $1.44 \%$, and were significantly $(p<0.05)$ different among the mayonnaise samples. Ash is the residue remaining after removing water and organic matter by heating in the presence of oxidizing agents (Fazal et al., 2015). It is a measure of the total amount of minerals in a food product like mayonnaise. Mayonnaise from oil blends had a higher ash content (1.14-1.34\%) than the control $(1.12 \%)$ but lower than $100 \%$ African pear pulp oil (SO:APO100) (1.44\%).

The ash content in this study was lower than $1.15-1.80 \%$ reported by Palma et al. (2004) for lowfat mayonnaise samples and $1.57 \%$ by Aswir et al. (2017) for mayonnaise sold in the Malaysian market but higher than $0.64 \%$ reported by Babajide and Olatunde (2010) for Heinz ${ }^{\circledR}$ mayonnaise. The values (1.14 to $1.57 \%$ ) reported by Amin et al. (2014) for low-fat mayonnaise containing different types and levels of hydrocolloid gum was close to the values obtained in this study. The higher ash content of the blended samples suggested the possible presence of higher mineral content, therefore greater tendency to enhance growth and development, and also catalyze metabolic processes in human body (Onwuka, 2014).

The fat content of the mayonnaise ranged from 30.15 to $37.15 \%$. There were significant differences $(p<0.05)$ among the mayonnaise samples. Mayonnaise produced from blended oil samples had higher fat contents. Fats influence the structure, rheological properties, and sensory characteristics of food products (Rios et al., 2014) like mayonnaise. The fat content in this study was higher than $29.68 \%$ reported by Babajide and Olatunde (2010) for Heinz $^{\circledR}$ mayonnaise but close to $30.76 \%$ reported by Aswir et al. (2017) and 30.29 to $33.40 \%$ reported by Palma et al. (2004). Hence, the fat content of the mayonnaise samples was generally high, and in turn correlate with the assertion that mayonnaise is a semi-solid oil-in-water emulsion containing high-fat (Amin et al., 2014). Diets with high fat content contribute significantly to the energy requirement for humans, in addition to aiding in proper absorption of fat-soluble vitamins (Aganovic et al., 2018).

The protein content ranged from $1.93 \%$ in the control to $2.31 \%$ in SO85:APO15 and was significantly $(p<0.05)$ different from each other. Although egg yolks and whites are sources of dietary protein, they differ in nutritional value including the amount of protein (Hasenhuettl, 2008). The variations in protein content observed in the mayonnaise samples may be attributed to the different formulations used

Table 4: Proximate composition of mayonnaise produced from soybean and African pear (Dacryodes edulis) pulp oil blends

\begin{tabular}{lccccc}
\hline Samples (\%) & Moisture content & Ash & Fat & Protein & Carbohydrate \\
\hline Control & $32.65 \pm 0.11^{\mathrm{d}}$ & $1.12 \pm 0.01^{\mathrm{c}}$ & $30.15 \pm 0.04^{\mathrm{f}}$ & $1.93 \pm 0.07^{\mathrm{e}}$ & $34.15 \pm 0.04^{\mathrm{a}}$ \\
SO0:APO100 & $33.01 \pm 0.03^{\mathrm{c}}$ & $1.44 \pm 0.01^{\mathrm{a}}$ & $37.15 \pm 0.11^{\mathrm{a}}$ & $2.23 \pm 0.01^{\mathrm{b}}$ & $26.17 \pm 0.02^{\mathrm{e}}$ \\
SO85:APO15 & $34.14 \pm 0.02^{\mathrm{b}}$ & $1.14 \pm 0.02^{\mathrm{d}}$ & $31.40 \pm 0.12^{\mathrm{e}}$ & $2.31 \pm 0.01^{\mathrm{a}}$ & $31.01 \pm 0.17^{\mathrm{b}}$ \\
SO75:APO25 & $34.26 \pm 0.04^{\mathrm{b}}$ & $1.23 \pm 0.01^{\mathrm{c}}$ & $32.08 \pm 0.10^{\mathrm{d}}$ & $2.28 \pm 0.02^{\mathrm{ab}}$ & $30.15 \pm 0.03^{\mathrm{c}}$ \\
SO65:APO35 & $34.83 \pm 0.02^{\mathrm{a}}$ & $1.27 \pm 0.02^{\mathrm{c}}$ & $34.35 \pm 0.07^{\mathrm{c}}$ & $2.08 \pm 0.01^{\mathrm{d}}$ & $27.47 \pm 0.01^{\mathrm{d}}$ \\
SO50:APO50 & $35.04 \pm 0.01^{\mathrm{a}}$ & $1.34 \pm 0.01^{\mathrm{b}}$ & $35.60 \pm 0.01^{\mathrm{b}}$ & $2.15 \pm 0.01^{\mathrm{c}}$ & $25.87 \pm 0.06^{\mathrm{f}}$ \\
\hline
\end{tabular}

SO - soybean oil, APO - African pear oil; numerical values standing for the percentages of each oil

Values (means \pm std dev. of duplicate determination) in the same column with different superscript are significantly different $(p<0.05)$. 
and variations in the protein content of each egg yolk. Egg yolks minimally consist of $56 \%$ fat (lipids) and $30 \%$ protein. It is an emulsifier that also acts as a colouring agent to the finished mayonnaise product. It is critical for the stability of the mayonnaise and other products such as salad dressing (Hasenhuettl, 2008) but contains slightly less protein than white eggs (USDA, 2014). Generally, mayonnaise contains $3-3.50 \%$ protein (Salazar-Villanea et al., 2016). The value of protein obtained in this study was lower than $2.96 \%$ reported by Babajide and Olatunde (2010) for Heinz ${ }^{\mathbb{R}}$ mayonnaise but was higher than the protein content (1.38 to $1.68 \%$ ) of mayonnaise with different egg yolk oil (Aleksandrs et al., 2016). The results of this work showed inadequate amount of protein present in these products.

The carbohydrate content of the mayonnaise samples ranged from 25.87 to $34.15 \%$. Samples containing higher proportion of African pear oil from had decreased carbohydrate content. The variation in the carbohydrate contents of the samples can be attributed to the variation in the values obtained in other parameters. The value of carbohydrate (19.75 to $20.74 \%$ ) reported by Gaikwad et al. (2017) for mayonnaise produced with skim milk powder and cardamom flavour as well as the value $(17.92 \%)$ reported for Heinz ${ }^{\circledR}$ mayonnaise (Babajide and Olatunde, 2010) were below the values obtained in this study.

\section{Physicochemical Properties}

The physicochemical properties of mayonnaise samples are presented in Table 5. The $\mathrm{pH}$ values ranged from 4.13 in SO85:APO15 to 4.23 in SO50:APO50. The samples did not differ significantly $(p<0.05)$ in their $\mathrm{pH}$ values. The $\mathrm{pH}$ of mayonnaise plays an important role in its structure and stability. Acidic $\mathrm{pH}$ improves the stability of mayonnaise by preventing microbial growth, thereby maintaining the structure of the mayonnaise. Notably, the $\mathrm{pH}$ of the mayonnaise samples increased with increase in African pear oil substitution, and this might be due to the higher $\mathrm{pH}$ of African pear oils which increases the $\mathrm{pH}$ of the samples upon addition. The values obtained in this study was higher than 3.78 to 3.91 reported for flavoured mayonnaise (Gaikwad et al., 2017) and 3.70 to 3.72 reported for mayonnaise produced from blends of virgin coconut and soybean seed oil (Belal et al., 2019), but within the range of values (4.05-4.07) obtained for mayonnaise processed with different egg yolk oil content by Aleksandrs et al. (2016). Generally, the $\mathrm{pH}$ of the samples are acidic in nature which might be beneficial in preventing the growth of spoilage microorganism and in turn enhance the stability of the mayonnaise samples.

The vitamin $\mathrm{E}$ content of the mayonnaise samples increased from 4.97 in the control to 16.24 $\mathrm{mg} 100 \mathrm{~g}^{-1}$ in SO50:APO50, which might be due to the richness of the African pear oil in vitamin $\mathrm{E}$ as reflected in mayonnaise $\left(22.60 \mathrm{mg} 100 \mathrm{~g}^{-1}\right)$ from $100 \%$ African pear oil. Vitamin E is a fat-soluble antioxidant that increases the oxidative stability of edible oils or its products (Rohit and Kanjan, 2018). The low vitamin E content obtained for mayonnaise sample produced from $100 \%$ soybean oil could be attributed to processing, such as, the refining process the oil was subjected to, especially deodorization, that have the capacity to reduce the tocopherol contents of the oil (Deiana et al., 2002). Blending both oils resulted to products with higher vitamin $\mathrm{E}$ composition. This implies that blending of African pear oil with soybean oil would improve the physicochemical and nutritional qualities of food products by delivering an improved fatty acid profile, increased stability and increased antioxidant and bioactive component content (Akriti et al., 2018). The values observed in this investigation were greater than $5.44 \mathrm{mg} 100 \mathrm{~g}^{-1}$ reported for mayonnaise by Aswir et al. (2017).

With increasing proportions of African pear oils, the total solids (TS) content of the mayonnaise samples decreased progressively from $70.37 \%$ to $60.30 \%$. The TS is the amount of solids remaining after heating the sample at $105^{\circ} \mathrm{C}$ to constant weight (Onwuka, 2018). It is one of the most often used tests in quality control for some food products like mayonnaise. The total solids influenced significantly, the stability of mayonnaise upon storage, preventing a collapse of its structure and entire matrix (Onwuka, 2018). TS is inversely correlated with moisture content, hence, higher TS recorded for the control may be associated with its lower moisture content than samples produced from oil blends. The value obtained in this study agrees with $65.70 \%$ reported by Gaikwad et al. (2017) for vanilla flavoured mayonnaise. Although, the TS of mayonnaise from oil blends had lower TS compared to the control, the values obtained indicated that the mayonnaise samples upon storage may have significant stability against deterioration upon storage.

Table 5: Physicochemical properties of mayonnaise samples produced from soybean and African pear pulp oil blends

\begin{tabular}{lccccc}
\hline Samples & $\mathrm{pH}$ & Vitamin E $\left(\mathrm{mg} \mathrm{100g}^{-1}\right)$ & Total solids $(\%)$ & Iodine value $\left({\left.\mathrm{g} 100 \mathrm{~g}^{-1}\right)}^{\text {Viscosity }(\text { Pa.s })}\right.$ \\
\hline Control & $4.18 \pm 0.03^{\mathrm{ab}}$ & $4.97 \pm 0.02^{\mathrm{d}}$ & $70.35 \pm 0.07^{\mathrm{a}}$ & $78.85 \pm 0.07^{\mathrm{e}}$ & $26.80 \pm 0.14^{\mathrm{e}}$ \\
SO0:APO100 & $4.21 \pm 0.02^{\mathrm{a}}$ & $22.60 \pm 0.41^{\mathrm{a}}$ & $68.10 \pm 0.14^{\mathrm{b}}$ & $28.70 \pm 0.14^{\mathrm{f}}$ & $24.70 \pm 0.14^{\mathrm{d}}$ \\
SO85:APO15 & $4.13 \pm 0.01^{\mathrm{b}}$ & $14.38 \pm 0.04^{\mathrm{c}}$ & $66.20 \pm 0.14^{\mathrm{c}}$ & $88.50 \pm 0.14^{\mathrm{d}}$ & $28.40 \pm 0.14^{\mathrm{c}}$ \\
SO75:APO25 & $4.17 \pm 0.01^{\mathrm{ab}}$ & $15.22 \pm 0.02^{\mathrm{bc}}$ & $64.40 \pm 0.14^{\mathrm{d}}$ & $86.80 \pm 0.07^{\mathrm{c}}$ & $28.65 \pm 0.07^{\mathrm{c}}$ \\
SO65:APO35 & $4.19 \pm 0.01^{\mathrm{ab}}$ & $15.81 \pm 0.01^{\mathrm{bc}}$ & $62.15 \pm 0.21^{\mathrm{e}}$ & $86.25 \pm 0.14^{\mathrm{b}}$ & $29.02 \pm 0.03^{\mathrm{b}}$ \\
SO50:APO50 & $4.23 \pm 0.01^{\mathrm{a}}$ & $16.24 \pm 0.00^{\mathrm{b}}$ & $60.30 \pm 0.14^{\mathrm{f}}$ & $83.10 \pm 0.14^{\mathrm{a}}$ & $30.13 \pm 0.03^{\mathrm{a}}$ \\
\hline
\end{tabular}

SO - soybean oil, APO - African pear oil; numerical values standing for the percentages of each oil

Values (means \pm std dev. of duplicate determination) in the same column with different superscript are significantly different $(p<0.05)$. 
The iodine value (IV) of the mayonnaise samples ranged from 28.70 to $88.50 \mathrm{~g}$ iodine $/ 100 \mathrm{~g}$ with significant differences $(p<0.05)$ existing among the samples. These values were higher than the value $\left(75.72 \mathrm{~g}\right.$ iodine $\left.100 \mathrm{~g}^{-1}\right)$ reported for mayonnaise produced with $50 \%$ soybean oil and $50 \%$ virgin coconut oil blends (Belal et al., 2019). The IV measures the degree of unsaturation (number of double bonds) of oils/oil-based products (Egbuonu et al., 2015). The IV of the mayonnaise samples increased significantly after blending. The increased IV reflect the level of unsaturation, hence, suggesting that mayonnaise from blended oils may have better nutritional and health benefits but might oxidise at a faster rate (Egbuonu et al., 2015).

The viscosity of the mayonnaise samples ranged from 24.70 to 30.13 Pa.s. Viscosity is one of the main factors which governs absorption and drainage of oil and oil-based products. It is affected by the level of interaction between the egg protein molecules and the oil-droplets (Izidoro et al., 2007). Mayonnaise produced from blended oil had higher viscosity (28.40-30.13 Pa.s) than the control (26.80 Pa.s) and SO0:APO100 (24.70 Pa.s), which might be attributed to better intermolecular interaction between the egg protein molecules and the newly formed oil droplets that resulted after blending, and possibly, creating a better balance between flow and stability. Mayonnaise viscosity is largely influenced by the intermolecular interactions between the egg protein molecules and oil droplets. The stronger the interaction, the better the consistency (viscosity) of the mayonnaise products. Possibly, the oil droplets that resulted after blending had better intermolecular interaction with egg protein molecules (Izidoro et al., 2007). Also, crude oils contain natural emulsifiers like phospholipids which could have played a part in improved emulsification in mayonnaise production. This study's viscosity obtained in this study was lower than the 170.0-476.2 Pa.s reported for mayonnaise processed with different egg yolk oils (Aleksandrs et al., 2016).

\section{Sensory Properties}

Sensory scores of mayonnaise samples produced from soybean and African pear oil blends are shown in Table 6. The scores for appearance and aroma ranged from 6.75 to 7.35 and from 6.65 to 7.85 , respectively. There were no significant differences $(p>0.05)$ in the appearance and aroma of the mayonnaise samples, which suggested that the blending of both oil (soybean and African pear oil) resulted to a finished product with similar acceptability as the control. Appearance is an important sensory feature of any food product as it influences acceptability. Consumers assess the quality of products with their eyes first and use the appearance to predict quality of food products (Oluwole, 2009) like mayonnaise.

It is one of the vital organoleptic properties of mayonnaise. The scores for taste ranged from 6.48 to 7.40. Notably, mayonnaise produced from oil blends samples had lower scores compared to the control samples. The lower scores signified that the blend of both oils was alien to the taste buds of the panelist. Taste is the sensation of flavour perceived in the mouth and throat on contact with a substance (Ogundele et al., 2015). It is one of the attributes that consumers look out for in mayonnaise. The consistency scores ranged from 6.80 to 8.00 . Consistency relates to the 'firmness', 'thickness' or 'viscosity' of a liquid or fluid semisolid. It is one of the quality attributes consumers' look out for in mayonnaise, as they desire a product that possess no lumps, uniform consistency and flow ability. The increasing viscosity of the mayonnaise samples produced from the oil blends may have negatively influenced the consistency scores. The panelist may have preferred the lighter consistency of the $100 \%$ pear oil-based samples to the thicker consistencies of the samples made from the blends. The SO0:APO100 had the highest score which may be due to the lighter viscosity that was preferred by panelist. Although the blended samples had lower scores but it was observed that increasing proportion of African pear oil resulted to mayonnaise samples with increasing consistency. Scores for overall acceptability ranged from 7.05 to 8.40. SO0:APO100 had the highest score possibly because it recorded the highest scores for all sensory parameters, particularly appearance and taste. This view was also supported by Ojinnaka and Nnorom (2015) who reported that taste of a food ultimately determines its acceptance or rejection even though its appearance evokes the initial response.

Table 6: Sensory evaluation of mayonnaise produced from soybean and African pear pulp oil blends

\begin{tabular}{lccccc}
\hline Samples & Appearance & Taste & Aroma & Consistency & Overall acceptability \\
\hline Control & $7.05 \pm 1.05^{\mathrm{a}}$ & $7.00 \pm 1.45^{\mathrm{a}}$ & $6.75 \pm 1.41^{\mathrm{b}}$ & $7.35 \pm 1.14^{\mathrm{ab}}$ & $7.15 \pm 1.60^{\mathrm{b}}$ \\
SO0:APO100 & $7.35 \pm 1.39^{\mathrm{ab}}$ & $7.40 \pm 1.23^{\mathrm{a}}$ & $7.65 \pm 1.09^{\mathrm{a}}$ & $8.00 \pm 1.08^{\mathrm{a}}$ & $8.40 \pm 0.88^{\mathrm{a}}$ \\
SO85:APO15 & $7.00 \pm 1.49^{\mathrm{a}}$ & $6.85 \pm 1.35^{\mathrm{b}}$ & $6.85 \pm 1.09^{\mathrm{b}}$ & $6.80 \pm 1.20^{\mathrm{b}}$ & $7.45 \pm 1.50^{\mathrm{b}}$ \\
SO75:APO25 & $6.75 \pm 1.41^{\mathrm{ab}}$ & $6.70 \pm 1.42^{\mathrm{b}}$ & $6.75 \pm 1.48^{\mathrm{b}}$ & $6.90 \pm 1.33^{\mathrm{b}}$ & $7.25 \pm 1.29^{\mathrm{b}}$ \\
SO65:APO35 & $7.25 \pm 1.02^{\mathrm{a}}$ & $6.45 \pm 1.39^{\mathrm{ab}}$ & $6.80 \pm 1.24^{\mathrm{b}}$ & $7.10 \pm 1.41^{\mathrm{b}}$ & $7.05 \pm 1.76^{\mathrm{b}}$ \\
SO50:APO50 & $7.35 \pm 1.98^{\mathrm{a}}$ & $6.85 \pm 1.23^{\mathrm{b}}$ & $6.70 \pm 1.03^{\mathrm{b}}$ & $7.50 \pm 1.40^{\mathrm{ab}}$ & $7.35 \pm 1.73^{\mathrm{b}}$ \\
\hline
\end{tabular}

SO - soybean oil, APO - African pear oil; numerical values standing for the percentages of each oil

Values (means \pm std dev. of duplicate determination) in the same column with different superscript are significantly different $(p<0.05)$. 


\section{CONCLUSION}

This study evaluated the production and quality assessment of mayonnaise from blends of African pear pulp oil and soybean oil. Findings from this study revealed that blending improved the quality properties of the blended oil samples, although the free fatty acid exceeded the CODEX recommended limit which necessitates refining. The mayonnaise samples produced from oil blends had higher ash content, fat, protein contents and lower carbohydrate contents than the control but may have shorter shelf stability. The vitamin $\mathrm{E}$, iodine value, and viscosity of the mayonnaise increased after blending while the sensory attributes were acceptable to panelists. African pear oil from underutilized African pear fruit should be utilized as an important ingredient and dietary source for food products like mayonnaise.

\section{CONFLICT OF INTEREST}

The authors declare no potential conflict of interest.

\section{REFERENCES}

Abitogun A.S. and Olasehinde E.F. (2012). Nutritional evaluation of seed and characterization of crude jack bean (Canavalia ensiformis) oil. J. Appl. Chem., 1 (6), $36-40$

Adedokun I.I. and Onuegbu N.C. (2011). The physical properties of pulp and chemical characteristics of edible oil extracted from the pulp of African pear (Dacryodes edulis). Pak. J. Nutr., 10 (6), 558-560

Aganovic K., Bindrich U. and Heinz V. (2018). Ultra-high pressure homogenization process for production of reduced fat mayonnaise with similar rheological characteristics as its full fat counterpart. Innov. Food Sci. Emerg. Technol., 45, 208- 214

Agbaire P.O. (2012). Quality assessment of palm oil sold in some major markets in Delta State, Southern Nigeria. Afr. J. Food Sci. Technol., 3 (9), 223-226

Akriti D., Rajni C. and Meenakshi G. (2018). A review on blending of oils and their functional and nutritional benefits. Chem. Sci. Rev. Letters, 7 (27), 840-847

Akusu O.M. and Wordu G.O. (2019). Physicochemical properties and fatty acid profile of Allan blackia seed and African pear pulp oils. Int. J. Biotechnol. Food Sci., 7 (2), 14-22

Akusu O.M., Wordu G.O. and Obiesie C. (2019). Effects of fat modification on the physicochemical properties and fatty acid profile of shortenings formulated with African pear (Dacryodes edulis) pulp oil and tallow tree (Allan blackia floribunda) seed oil. Int. J. Nutr. Sci. Food Technol., 5 (2), 12-19

Al-Bachir M. (2015). Quality characteristics of oil extracted from gamma irradiated peanut (Arachis hypogea L.). Radiation Phys. Chem., 106, 56-60

Aleksandrs K., Evita S. and Māra D. (2016). The effect of egg yolk oil on the chemical, physical and sensory properties of mayonnaise. Rural Sustain. Res., 35 (330), 24-31

Amin M.H., Elbeltagy A.E., Mahmoud M. and Khalil A.H. (2014). Development of low fat mayonnaise containing different types and levels of hydrocolloid gum. J. Agroaliment. Process. Technol., 20 (1), 54-63
Amos-Tautua B. and Onigbinde A. (2013). Physicochemical properties and fatty acid profiles of crude oil extracts from three vegetable seeds. Pak. J. Nutr., 12 (7), 647-650

Ankapong E. (2010). The Influence of Physicochemical Characteristics of Vegetable Oils on the Quality of Biodiesel Produced from Palm Oil, Palm Kernel Oil, Refined Soybean Oil, Unrefined Soybean Oil and Jatropha Curcas Oil. A Thesis, School of Graduate Studies, Kwame Nkrumah University of Science and Technology, Kumasi, pp. 133-136

AOAC (2012). Official Methods of Analysis (19 $9^{\text {th }}$ ed.). Association of Official Analytical Chemist, Washington DC, p. 210

AOCS (1993). Official Methods and Recommended Practices of the American Oil Chemists' Society Champaign. American Oil Chemists' Society Method Cd 1d-92

Arrisson A.R., Roland A., Emmanuel N.K., Brise-Amian B.K. and Louise O. (2019). Effect of solvent and press extractions on physicochemical properties of oil extracted from Dacryodes edulis fruit. Asian J. Sci. Technol., 10 (3), 9559-9564

ASTM (2011). American Society of Testing and Materials D445-06, Standard Test for Kinematic Viscosity. UW Madison Formula SAE Department of Chemistry University of California - Davis, CA 95616, Chemistry 2B Laboratory Manual, Summer

ASTM (2012). American Society of Testing and Materials D5768-02, Annual Book of ASTM Standards, ASTM International, West Conshohocken, 619

Asuquo J.E., Etim E.E., Ukpong I.U. and Etuk S.E. (2012). Extraction, characterization and fatty acid profile of Poga oleosa oil. Int. J. Modern Analyt. Separat. Sci., 1 (1), 23-30

Aswir A.R., Noh M.F., Khalid N.M. et al. (2017). The nutritional composition of mayonnaise and salad dressing in the Malaysian market. Sains Malaysiana, 46 (1), 139-147

Atinafu D.G. and Bedemo B. (2011). Estimation of total free fatty acid and cholesterol content in some commercial edible oils in Ethiopia, Bahir DAR. $J$. Cereal. Oil Seed., 2, 71-76

Babajide J.M. and Olatunde O.O. (2010). Proximate composition, rheology and sensory quality of corn cocoyam salad cream. World J. Dairy Food Sci., 5 (1), 25-29

Belal J.M., Ley L.Y., Abd-Elaziem F. and Anis S.H. (2019). Valorisation of virgin coconut oil application in mayonnaise production as functional ingredient. $J$. Food Nutr. Res., 7 (1), 65-70

CODEX (1999). Standard for named vegetable oils. Codex Alimentarius Commission Codex-Stan, 210. Accessed 23 Jun. 2020 from http://www.codexali mentarius.net/search/advancedsearch.do

Deiana M., Rosa A., Cao C.F., Pirisi F.M., Bandino G. and Dessi M.A. (2002). Novel approach to study oxidative stability of extra virgin olive oils: importance of atocopherol concentration. J. Agric. Food Chem., 50, 4342-4346

Egbuonu A.C., Aguguesi R.G., Samuel R., Ojunkwu O., Onyenmeri F. and Uzuegbu U. (2015). Some physicochemical properties of the petroleum etherextracted watermelon (Citrullus lanatus) seed oil. Asian J. Sci. Res., 8 (4), 519-525 
Enengedie I.S., Ekpa O.D. and Ikpi M.E. (2019). Comparative study on the cosmictutcal properties of oil from Dacryodes edulis and Persea americana fruits. Am. J. Chem., 9 (1), 13-20

FAO/WHO (2009). Report of the $21^{\text {st }}$ session of the codex alimentarius committee on fats and oils. Joint FAO/WHO Food Standard Programme Codex Alimentarius Commission, 16-20 February, Kola Kinabalu, Malaysia

Fazal W., Musa K., Mohsan N. and Khakemin K. (2015). Comparison of some physicochemical properties of different oils available in the local market in Pakistan. Int. J. Recent Res. Aspect., 2 (2), 93-98

Gaikwad M., Syed H. and Shinde D. (2017). To study the physicochemical properties of flavoured mayonnaise. J. Pharmacog. Phytochem., 6 (5), 06-09

Ghulam R., Sarfraz H., Zafar A. and Muhammad S.I. (2013). The effect of corn oil on the quality characteristics of mayonnaise. Am. J. Food Sci. Technol., 1 (3), 45-49

Hasan K., Hossain B., Dhar P. and Haque R. (2019). Comparative study on cholesterol content and physicochemical properties of some branded and unbranded commercial edible oils in Khulna, Bangladesh. J. Chem. Health Risks, 9 (4), 321-329

Hasenhuettl G.L. (2008). Analysis of food emulsifiers. In: Hasenhuettl G.L., Hartel R.W. (eds.), Food Emulsifiers and their Applications (pp. 11-37). Springer Science, New York

Ikya J., Umenger L. and Iorbee A. (2013). Effects of extraction methods on the yield and quality characteristics of oils from shea nut. J. Food Resour. Sci., 2, 1-12

Isaac I.O., Ekpa O.D. and Ekpe U.J. (2014). Extraction, characterization of African pear oil and its application in synthesis and evaluation of surface coating dries. Int. J. Adv. Res. Chem. Sci., 1 (4), 14-22

Iwe M. O. (2014). Current Trends in Sensory Evaluation of Foods (revised edition). Rojoint Communication Services Ltd, Uwani Enugu, Nigeria. pp. 144-145

Izidoro D., Sierakowski M., Waszczynskyj N., Haminiuk C. and Scheer A. (2007). Sensory evaluation and rheological behavior of commercial mayonnaise. Int. J. Food Eng., 3 (1), 5. https://doi.org/10.2202/15563758.1094

Katkade M., Syed H., Andhale R. and Farooqui A. (2018). Comparative study of physicochemical properties of different edible vegetable oils. J. Multilogic Sci. Agric. Eng., 8 (25), 235-238

Kusuma N.B. (2015). Soybean consumption and health benefits. Int. J. Sci. Technol. Res., 4 (7), 50-53

Mateos-Asparicio I., Redondo C.A., Villanueva-Suarez M.J., Zapata-Revilla M.A. (2008). Soybean, a promising health source. Nutricionhospitalaria 23 (4), 272-283

Mengistie T., Alemu A. and Mekonnen A. (2018). Comparison of physicochemical properties of edible vegetable oils commercially available in Bahir Dar, Ethiopia. Chem. Int., 4 (2), 130-135

Miguel L.M., Mokondjimobe E., Okiemy-Andissa N. et al. (2017). Medicinal potentials of Dacryodes edulis (G.Don) H.J. Lam: Literature review. Int. J. Current Res., 9 (12), 63014-63018

Mirzanajafi-Zanjani M., Yousefi M. and Ehsani A. (2019). Challenges and approaches for production of a healthy and functional mayonnaise sauce. Food Sci. Nutr., $7(8), 2471-2484$
Muhammad S.I., Ghulam R., Sarfraz H. and Zafar A. (2013). Effect of corn oil on the quality characteristics of mayonnaise. Pak. J. Nutr., 12 (9), 860-864

Musa U., Isah A.G., Mohammed I.A., Mohammed U.G. and Usman Z. (2015). Extraction of Chrysophyllum albidum seed oil: Optimization and characterization. Chem. Process Eng. Res., 30, 1-8

Nangbes J.G., Nvau J.B., Buba W.M. and Zukdimma A.N. (2013). Extraction and characterization of castor (Ricinus communis) seed oil. Int. J. Eng. Sci., 2 (9), 105-109

Ndah N., Egbe E., Bechem E., Asaha S., Yengo T. and Chia E.L. (2013). Ethnobotanical study of commonly used medicinal plants of the Takamanda rainforest, Southwest, Cameroon. Afr. J. Plant Sci., 7 (1), 21-34

Noumi G.B., Djounja T., Ngameni E. and Kapseu C. (2014). Influence of the storage time on the fats and oil composition of safou (Dacryodes edulis) dried pulp. Int. Food Res. J., 21 (5), 1837-1841

O'Keefe S., Bianchi L. and Sharman J. (2015). Soybean nutrition. SM J. Nutr. Metab., 1 (1), 1-9

Ochigbo S. and Paiko Y. (2011). Effects of solvent blending on the characteristics of oils extracted from the seeds of Chrysophyllum albidium. Int. J. Sci. Nature, 2 (2), 352-358

Ogundele G.F., Ojubanire B.A. and Bamidele O.P. (2015). Proximate composition and organoleptic evaluation of cowpea (Vigna unguiculata) and soybean (Glycine max) blends for the production of moi-moi and ekuru (Steamed cowpea paste). J. Exp. Biol. Agric. Sci., 3 (2), 207

Ojinnaka M. and Nnorom C. (2015). Quality evaluation of wheat-cocoyam-soybean cookies. Nig. J. Agric. Food Environ., 11 (3), 123-129

Okolo C.A., Ejere V.C., Chukwuka C.O., Ezeigbo I.I., Nwibo D.D. and Okorie A.N. (2016). Hexane extract of Dacryodes edulis fruits possesses anti-diabetic and hypolipidaemic potentials in alloxan diabetes of rats. Afr. $J$. Trad. Complement. Alternat. Med., 13 (4), 132-144

Okonkwo S.I. and Okafor E.C. (2016). Determination of the proximate composition, physicochemical analysis and characterization of fatty acid on the seed and oil of Gossypium hirsutum. Int. J. Chem., 8 (3), 57-61

Oluwole A. (2009). Quality control for the food industry: A statistical approach. Concept Publications Ltd., Lagos, Nigeria, pp. 229-235

Omonhinmin A.C. (2014). Ethnobotany of Dacryodes edulis (G. Don) H.J. Lam in Southern Nigeria: Practices and applications among the Yoruba speaking people. Ethnobotany Res. Appl., 10, 071-080

Onoriode O., Oluwabukola J., Beatrice A., Ibukunoluwa A., Usman Y. and Godfrey A. (2015). Fatty acids profile and physicochemical properties of Citrullus vulgaris seed oil. Chem. Mater. Res., 7 (5), 77-81

Onwuka G.I. (2014). Food Science and Technology. Naphtali Prints Lagos, Nigeria, p. 297

Onwuka G.I. (2018). Food Analysis and Instrumentation: Theory and Practices (Revised ed.). Naphtali Prints Lagos, Nigeria

Onwuzuruike U.A., Nwose O.N., Offia-Olua B.I., Uzochukwu U.C. and Madubuko S.C. (2020). Characterization of Dacryodes edulis (African pear) pulp oil obtained with different extraction methods. FUTO J. Series, 6 (2), 201-214

Palma A., Aziz M., Chawdhury M., Uddin B. and Alam M. (2004). Effect of edible oils on quality and shelf life of low fat mayonnaise. Pak. J. Nutr., 3 (6), 340-343 
Presscott S.A. and Board R.G. (1993). Food Technology ( $1^{\text {st }}$ ed.). McGraw-Hill Book Co., Inc., NY and London

Ravisankar P., Reddy A.A., Reddy A. et al. (2015). The comprehensive review on fat soluble vitamins. IOSR J. Pharm., 5 (11), 12-28

Rebolleda S., Rubio N., Beltrán S., Sanz M. and GonzálezSanjosé M. (2012). Super-critical fluid extraction of corn germ oil: Study of the influence of process parameters on the extraction yield and oil quality. $J$. Supercritical Fluids, 72, 270-277

Rios R., Pessanha M., Almeida P., Viana C. and Lannes S. (2014). Application of fats in some food products. Food Sci. Technol., 34 (1), 3-15

Rohit S. and Kanjan U. (2018). Recovery of vitamin E from edible oil - A review. Int. J. Eng. Res. Technol., 7 (8), 11-19

Roiaini M., Ardiannie T. and Norhayati H. (2015). Physicochemical properties of canola oil, olive oil and palm olein blends. Int. Food Res. J., 22 (3), 1227-1233

Sadoudi R. and Ali-Ahmed D. (2017). Studies on physicochemical characteristics and fatty acid composition of commercially available Algerian frying edible oils. Int. Food Res. J., 24 (1), 60-67

Salazar-Villanea S., Hendriks W.H., Bruininx E., Gruppe H. and van-der A. (2016). Protein structural changes during processing of vegetable feed ingredients used in swine diets: Implications for nutritional value. Nutr. Res. Rev., 29 (1), 126-141
Sharma S., Goyal R. and Barwal S. (2014). Domestic processing effects on physicochemical, nutritional and anti-nutritional attributes in soybean (Glycine $\max \mathrm{L}$. Merill). Int. Food Res. J., 20 (6), 3203-3209

Sunmonu M.O., Ajala E.O., Odewole M.M., Morrison S. and Alabi A. (2016). Comparative analysis of physicochemical properties of oil extract from two varieties of fluted pumpkin seeds using different extraction methods. J. Sci. Eng. Technol., 13 (2), 48-60

Ukom A.N., Nwaru J. and Obeta A.N. (2018). Assessment of the physicochemical properties of selected brands of vegetable oils sold in Umuahia metropolis, Abia State, Nigeria. Nig. Food J., 36 (2), 10-17

USDA (2014). National nutrient database for standard reference release 27. Available at: www.ars.usda.gov/ $\mathrm{ba} / \mathrm{bhnrc} / \mathrm{ndl}$

Yang Y., Song X., Sui X. et al. (2016). Rosemary extract can be used as a synthetic antioxidant to improve vegetable oil oxidative stability. Ind. Crop. Products, 80, $141-147$

Yildirim M., Sumnu G. and Sahin S. (2016). Rheology, particle-size distribution, and stability of low-fat mayonnaise produced via double emulsions. Food Sci. Biotechnol., 25 (6), 1613-1618

Zahir E., Saeed R., Hameed M. and Yousuf A. (2014). Study of physicochemical properties of edible oil and evaluation of frying oil quality by fourier transforminfrared (FT-IR) spectroscopy. Arab. J. Chem., 5, 1-7 